\title{
Essential and Non-Essential Metals Profile in Blood of some Nigerian Pregnant Women
}

\section{*YAHAYA ${ }^{1}$ MI.; OGUNFOWOKAN ${ }^{2}$ AO; ORJI ${ }^{3}$ EO}

\author{
${ }^{I}$ Chemistry Department, Sokoto State University, Sokoto State, Nigeria \\ ${ }^{2}$ Chemistry Department, Obafemi Awolowo University, Ile - Ife, Nigeria. \\ ${ }^{3}$ Geneacology and Obstetrics Department, Obafemi Awolowo University, Ile - Ife, Nigeria. \\ *Corresponding Author:. Email-mansur_yahaya@yahoo.com Mobile: +234 7037928905
}

KEY WORDS: Blood, Pregnant Women, Metals, Nigeria

\begin{abstract}
In this study, the concentrations of some essential $(\mathrm{Ca}, \mathrm{Cu}, \mathrm{Fe}, \mathrm{Mg}, \mathrm{Mn}, \mathrm{Ni}$, and $\mathrm{Zn})$ and non-essential metals $(\mathrm{Cd}$ and $\mathrm{Pb})$ were determined in blood of pregnant women aged between $15-45$ years and enrolled at the Obafemi Awolowo University Teaching Hospitals Complex, Ile - Ife, Nigeria, for antenatal care. Fifty samples of whole blood were collected from the pregnant women and twenty five samples from non pregnant women as control. Levels of essential and non- essential metals were determined by atomic absorption spectrophotometry. The analyses were performed in order to assess the body burden of pregnant women with the metals and the health implications of the latter to pregnant women and their fetuses. Data analysis by descriptive and inferential statistics revealed that age, education, and profession correlate with the levels of the metals. The mean levels of the two non-essential metals obtained in this study were lower than the recommended limits for whole blood. While compared with other studies of pregnant women elsewhere results obtain were generally higher. Generally the values obtained in this study have indicated no serious body burden on the pregnant women. The importance of establishing factors that influence low human exposure concentrations is becoming critical in efforts to reduce exposures and hence the potential for adverse health effects. OJASEM
\end{abstract}

http://dx.doi.org/10.4314/jasem.v18i4.14

\section{INTRODUCTION:}

In recent years awareness has raised that essential and non-essential metals play an important role, as beneficial as well as harmful, for human health. This knowledge has challenged some of our old concepts about the causes of health problems and nutritional concepts (Hinwood et al. 2013, Isabelle et al. 2013, Boekelheide et al. 2013). Some metals widely distributed in nature play vital roles in growth and maintenance of health of the human body, as proteins, vitamins, essential amino acids and lipids do (Ogunfowokan et al. 2009, Sabrina et al. 2013, Kippler et al. 2012). In almost every biochemical process in body cells there are certain essential metals involved. Inadequacy or imbalance of these metals supply to a living system consequently affects a number of physiological functions (Yahaya et al. 2010, Koureas et al. 2012, Llop et al. 2013).

The physiological importance of micrometals and macro metals in human organism is well documented (Ezen and Kragelj 2006, Ogunfowokan et al. 2008). Variation of micro metals in body fluids such as blood, plasma and saliva could be informative of the genetic health. Changes of selected macro- and micrometals in blood plasma depending on age were observed and significant changes of the concentrations of calcium (from 2.5 to $5.0 \mathrm{mmol} \mathrm{L}^{-1}$ ), magnesium (from 0.9 to $1.5 \mathrm{mmol} \mathrm{L}^{-1}$ ), zinc (from 40 to $62 \mu \mathrm{mol} \mathrm{L}{ }^{-1}$ ) and iron (from 26 to $9.9 \mu \mathrm{mol} \mathrm{L}{ }^{-1}$ ) in the blood of females during different biological periods were determined (Lidia et al. 2012). Different conditions that prevent the development of changes in blood plasma concentrations of micrometals that occur during prolonged restriction of muscular activity have been evaluated also.

Recent developments in instrumentation have lowered the detection limits of trace metals to the low nanogram or even picogram range, thus enabling their determination in concentrations in the of range of microgramme per litre $\left(\mu \mathrm{g} \mathrm{L}^{-1}\right)$ or microgramme per kilogramme $\left(\mu \mathrm{g} \mathrm{kg}^{-1}\right)$, in some cases even less. Since most essential trace metals are present in biological specimens at low concentrations, precise and accurate analysis is essential if meaningful results are to be obtained (Michael et al. 2011, Koutra et al. 2012, Callan et al. 2013).

In Nigeria and some developing countries, the relation between essential and non-essential metals and human health has been studied scarcely, most of the studies are more concentrated towards the biochemical changes caused by an increased intake of metals in relation to alteration of metal metabolism however more studies in this field are essential to obtain the base - line levels, hence the need for the present study with specific objective of determining 
the levels of some essential and non-essential metals profile in blood of pregnant women using Atomic Absorption Spectrophotometer after microwave induced digestion and predicting the metals body burden in the pregnant women.

Reagents and apparatus : Nitric acid (HNO3 65\%), Metallic salts (Cadmium chloride [ $\mathrm{CdCl} 2$ 99\%], Copper (II) Chloride [CuCl2 99\%], Iron (II) chloride [FeCl2 98\%], Lead (II) Chloride [ $\mathrm{PbCl} 2$ 98\%], Nickel (II) Chloride [NiCl2 98\%] and Zinc bromide [ $\mathrm{ZnBr} 2$ 99\%]) and Hydrogen peroxide (H2O2 30\%), used were of analytical grade (Sigma Aldrich Chemicals Corporation). Glass wares (Polyethylene bottles and Teflon beakers) and sample containers (50 $\mathrm{mL}$, Fisher Scientific) used were thoroughly washed with non-ionic detergent solution and rinsed with ultrapure distilled water (resistivity $>18 \mathrm{M} \Omega \mathrm{cm}$ ), followed by soaking in $10 \%$ nitric acid $(65 \%$, Sigma Aldrich Chemicals Corporation) for 48 hours and finally rinsed with ultrapure distilled water

\section{METHODOLOGY:}

Ethical clearance was obtained from the authority of the Obafemi Awolowo University Teaching Hospitals Complex (O.A.U.T.H.C) Ile-Ife, Nigeria prior to sample collection. All studied pregnant women irrespective of age, profession, educational level or personal habits were diagnosed normal by trained physicians after they had undergone normal routine medical examinations. Informed consent and information on age, occupation and personal habits were obtained from the pregnant women by administration of questionnaire.

Blood samples were collected at the Labour Ward Unit of the O.A.U.T.H.C by qualified medical personnel using standard clinical procedure. Fifty samples of the whole blood were collected from pregnant women of age between $15-45$ years. Twenty five non-pregnant women blood was collected to serve as controls. The blood samples were collected shortly before delivery.

To establish the validity of results and reliability of the analytical procedures described in this study, recovery experiment was carried out since certified blood reference materials were not available to us when this study was conducted. Two milliliters of the blood samples were spiked with $10 \mathrm{ppm}$ of $\mathrm{Zn}, \mathrm{Cu}$, $\mathrm{Cd}, \mathrm{Pb}, \mathrm{Ni}$, and $\mathrm{Fe}$ in separate Teflon beakers and digested. The digested spiked samples were made up to mark in a $100 \mathrm{~mL}$ volumetric flask with ultrapure distilled water (resistivity $>18 \mathrm{M} \Omega \mathrm{cm}$ ). The workedup samples were stored in Polyethylene containers at $4^{0} \mathrm{C}$ prior to Flame Atomic Absorption Spectroscopy (FAAS) analyses. Also a $10 \mathrm{~mL}$ each of $10 \mathrm{ppm}$ of the standards were taken for FAAS analyses so that the results obtained can be compared with those of the spiked blood samples to obtain the recovery. The recovery was done in triplicate.

A Chemtech Analytical Alpha-4 (UK) Flame Atomic Absorption Spectrophotometry (FAAS) available at the Central Science Laboratory, Obafemi Awolowo University, Ile-Ife Nigeria was used to analysed the concentrations levels of the metals in the digested matrices.

Mean results of metals in blood samples were calculated from three replicate measurements and the standard deviation evaluated. The mean values were used for the general evaluation of data

Digestion using the Microwave induced Acid Digestion Method [MWD]: Blood samples were digested by the microwave induced acid digestion method by adopting the method of Memon et al. (2007) in other to achieve a shorter digestion time. Accurately $0.5 \mathrm{~mL}$ of whole blood was taking into Pyrex flask. Three milliliters of freshly prepared mixture of concentrated nitric acid and hydrogen peroxide $\left[\mathrm{HNO}_{3}-\mathrm{H}_{2} \mathrm{O}_{2}\right](2: 1 \mathrm{~V} / \mathrm{V})$ were added to each sample and stood for 10 minutes. They were then heated following a one-stage digestion programmed at $80 \%$ of the total power in a Sharp Light - up (Dial) domestic microwave oven with maximum heating power of $800 \mathrm{~W}$ for 3 minutes. After this the digestion flasks were cooled. The resulting solutions were evaporated to semidried mass to remove excess acid, and diluted with $0.1 \mathrm{M}$ nitric acid and transferred into a $100 \mathrm{~mL}$ volumetric flask. This was further diluted to the mark of the volumetric flask using ultrapure distilled water (resistivity $>18 \mathrm{M} \Omega$ $\mathrm{cm})$. The worked-up samples were stored in polyethylene containers in a refrigerator at $4{ }^{0} \mathrm{C}$ prior to FAAS analysis. A blank extraction (without the samples) was carried out through the complete procedure using ultrapure distilled water (resistivity > $18 \mathrm{M} \Omega \mathrm{cm})$.

\section{RESULTS AND DISCUSSION}

The results of the recovery experiment for blood samples using the microwave induced acid digestion method were obtained as percentage recoveries of $\mathrm{Cd}$, $\mathrm{Cu}, \mathrm{Fe}, \mathrm{Ni}, \mathrm{Pb}$ and $\mathrm{Zn}$ and are presented in Figure 1 the percentage recoveries of the metals ranged from $79 \% \mathrm{Cd}$ to $99 \% \mathrm{Zn}$. The high percentage recoveries obtained from microwave induced acid digestion method make it to be an efficient method. The method also saves time: less than four minutes are required to complete the digestion of the biological samples in this study. 


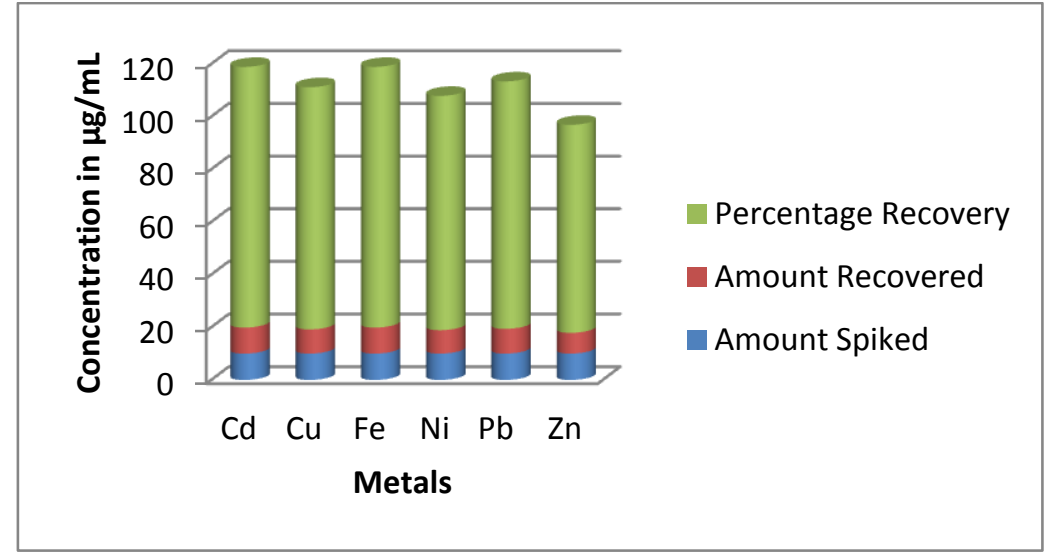

Fig 1 Percentage Recoveries of Metals

Based on the age group (Figure 2) this study revealed that women within age group of 25-29 represent the largest population (19 people) constituting $38 \%$ of all the pregnant women whose blood was analysed. This is not surprising as this is the average age range of women's child bearing in the study area. Women within age group of $15-19$ years however represent the least population ( 2 people). The most abundant element in the blood of the pregnant women is Magnesium followed by Calcium; Cd however, was the least abundant. Furthermore it was observed in this study that all the metals analysed were most abundant in the blood of pregnant women within the age group 25-29 years when compared with blood samples analysed from other age groups.

Fig 2 : Mean Metals Concentration $(\mu \mathrm{g} / \mathrm{mL})$ in Blood of Pregnant Women with Age Group

Results of variation in the levels of metals in blood of the pregnant women studied based on profession as shown in Figure 3, revealed that, forty percent $(40 \%)$ of the total subjects studied were businesswomen, followed by civil servants $(22 \%)$ while bankers and students ranged lowest with the population percentage of $8 \%$ respectively. It was also revealed that, $\mathrm{Pb}$ concentrations in blood were $4.18 \mu \mathrm{g} / \mathrm{mL}$ for bankers, $7.32 \mu \mathrm{g} / \mathrm{mL}$ for business women, 7.25 $\mu \mathrm{g} / \mathrm{mL}$ for civil servants, $9.76 \mu \mathrm{g} / \mathrm{mL}$ for nurses, 5.77 $\mu \mathrm{g} / \mathrm{mL}$ for students and $6.75 \mu \mathrm{g} / \mathrm{mL}$.

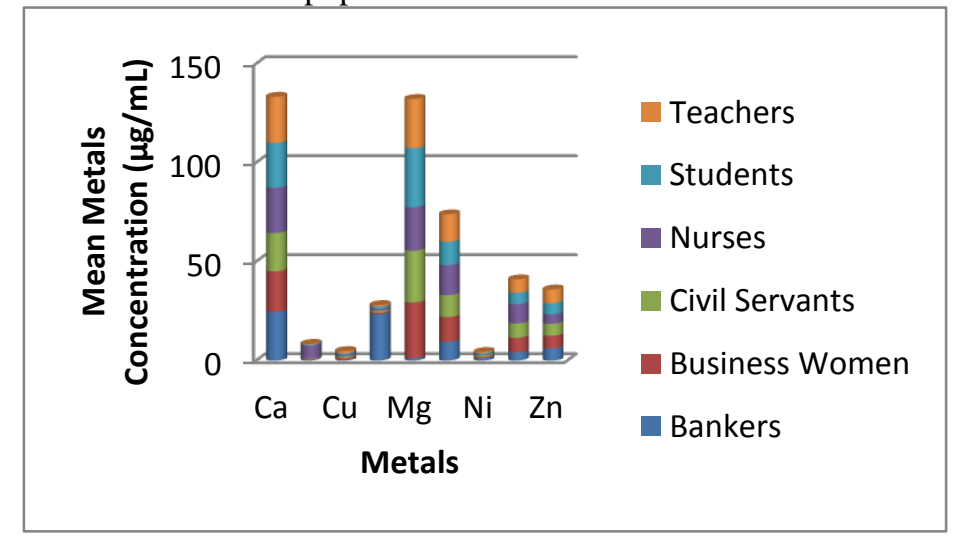

Fig 3 Mean Metals Concentration $(\mu \mathrm{g} / \mathrm{mL})$ in Blood of Pregnant Women with their Profession 
Higher levels of $\mathrm{Pb}$ reported in the subjects irrespective of their professions, may be due to intake of lead from food, water and air under normal conditions and perhaps from their exposures to lead from road sides. In this study the highest concentrations of non - essential metals were detected in blood samples of Nurses $(6.63 \mu \mathrm{gCd} / \mathrm{mL})$; Bankers $(1.24 \mu \mathrm{gNi} / \mathrm{mL})$ and Nurses $(9.76 \mu \mathrm{gPb} / \mathrm{mL})$.
The high levels of lead in nurses may be due to medical and routing procedure in the ward of cleaning feacal, urinary and blood matrices that exposed them to toxic metals and use of radiation releasing machineries and exposures from the roads, which is a source of lead from vehicular exhaust as a result of leaded petrol that is still in use in the country despite its ban since 2004 (Ogunfowokan et al. 2009).

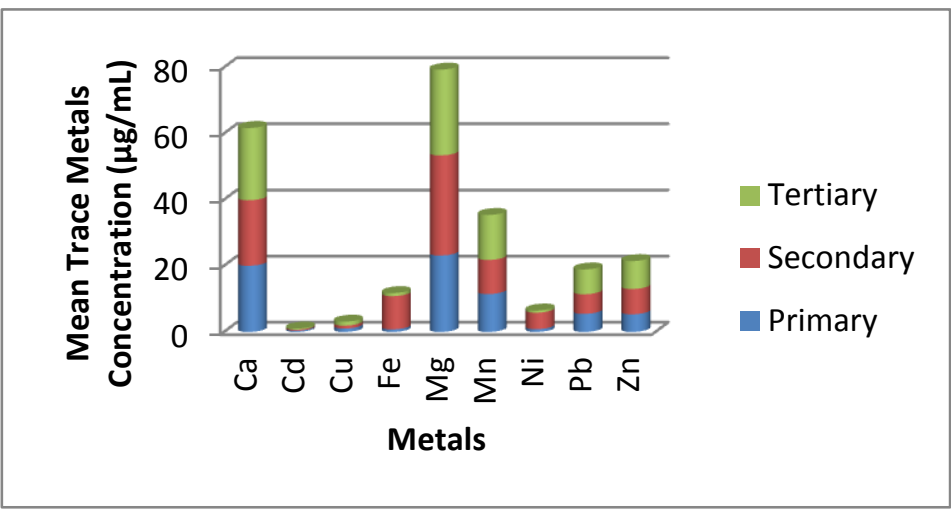

Fig 4 Mean Metals Concentration $(\mu \mathrm{g} / \mathrm{mL})$ in Blood of Pregnant Women with their Educational Background

In Figure 4, majority of subjects studied had tertiary education (36 people) representing $72 \%$, this is not surprising because studies have shown that the less educated pregnant women (primary and secondary education subjects) prefer to go to mission houses or traditional birth attendants houses for delivery. The reason for this is that they are either not able to settle hospital bills since they belong to low income class or their religious belief (Bello et al. 2009, Godfrey and Rockers, 2009, Itinal 1997). Varied levels of essential metals ranges were reported irrespective of the educational background. This gives cause for concern as good nutrition which is the source of these essential metals is very important for pregnant women. For example, Calcium has several important functions in the formation of bone and dental tissue, in the releasing of hormones, contraction of muscles and glycogen metabolism (Funda, 2004). The above calcium values obtained were much lower compared with the $1200 \mathrm{mg}$ recommended dietary allowance by national academy of sciences (NAS, 1974) in USA. Copper concentrations levels in blood of the pregnant women reported in this study were lower than the serum $\mathrm{Cu}$ levels of between 601 and $1373 \mathrm{~g} / \mathrm{L}$ reported by Minoia and Burtis (1990) and Burtis and Ashwood (1996).

Results of metals mean concentrations in blood $(\mu \mathrm{g} / \mathrm{mL})$ based on smoking and drinking habits shows that all the subjects that participate in the study were non - smokers. Overall mean concentration of cadmium was $0.82 \mu \mathrm{g} / \mathrm{mL}$ in the blood of non smoking subjects which is higher than the reported median blood cadmium (B-Cd) concentration in Slovenia of $0.50 \mu \mathrm{g} / \mathrm{L}$ in non-smokers, $1.00 \mu \mathrm{g} / \mathrm{L}$ in light - to -moderate smokers (less than 20 cigarettes/day) and $1.50 \mu \mathrm{g} / \mathrm{L}$ in heavy smokers (more than 20 cigarettes/day) by (Erzen, 2006). The high mean values of $\mathrm{Cd}$ reported in this study for non smoking subjects is of great concern considering the lower values reported for smoking subjects of Slovenia. For non-smokers, food constitutes the principal environmental source of cadmium. Drinking-water generally contains low cadmium levels, and a value of $1 \mu \mathrm{g} / \mathrm{L}$ or less is often assumed to be a representative content in most situations. Thus, cadmium exposure from drinking-water is relatively unimportant compared with the dietary contribution (Kippler et al. 2012).

Essential and non-essential metals level in the blood of the pregnant women with their drinking habit indicated that, ninety six percent $(96 \%)$ of the total subjects investigated in the study are non - drinkers. The levels of metals in the blood of subjects that drink ranged from $0.12 \mu \mathrm{gCd} / \mathrm{mL}$ to $18.25 \mu \mathrm{gCu} / \mathrm{mL}$, while in blood samples of subjects with no drinking habit the levels ranged from $2.88 \mu \mathrm{gCu} / \mathrm{mL}$ to 146.4 $\mu \mathrm{gCa} / \mathrm{mL}$. The results obtained in this study generally showed that levels of $\mathrm{Ca}$ in blood of both drinking and non drinking subjects was the highest, while those reported for $\mathrm{Cd}$ ranked lower only in the subjects without drinking habit. The high levels of $\mathrm{Cd}$ reported in blood of subjects without drinking habit in this study is surprising and unexpected and gives cause for concern. The relationship may be due to the low dietary calcium which stimulates synthesis of a calcium, binding protein which enhance cadmium absorption (Funda et al. 2004).

Blood provides information about what the body has recently (hours to days in some cases weeks) 
absorbed. Generally metals levels reported in this study were different from those reported in the study of metals analysis in kidneys and liver from human cadavers by Ogunfowokan (2008), which may be in agreement with Memon (2007) statement that, metals blood levels are largely independent of tissue deposition. The high levels of metals in pregnant women may be due to the improvement in diet during pregnancy as majority of the subjects in this study are educated, so are expected to be aware of the need to eat rich diet which is a major source of essential metals, despite reports of diet restrictions and nutritional aversion during pregnancy based on health, religion and tradition in the study area (Oboro et al. 2003, Ojofeitimi et al. 1982, Fei and Olsen, 2011).

In non - pregnant (controls) women level of essential and non-essential metals in blood were: $\mathrm{Ca}(28.38$ $\left.\mu \mathrm{gmL}^{-1}\right), \mathrm{Cd}\left(0.67 \mu \mathrm{gmL}^{-1}\right), \mathrm{Cu}\left(1.16 \mu \mathrm{gmL}^{-1}\right), \mathrm{Fe}(0.91$ $\left.\mu \mathrm{gmL}^{-1}\right), \quad \operatorname{Mg}\left(46.23 \mu \mathrm{gmL}^{-1}\right), \operatorname{Mn}\left(29.04 \mu \mathrm{gmL}^{-1}\right)$, $\mathrm{Ni}\left(1.18 \mu \mathrm{gmL}^{-1}\right), \quad \mathrm{Pb}\left(8.05 \mu \mathrm{gmL}^{-1}\right)$ and $\mathrm{Zn}(8.83$ $\left.\mu \mathrm{gmL}^{-1}\right)$. These values were lower than reported concentrations of metals in pregnant women blood in other studies (Gallagher et al. 2011, Jain, 2010, Tofail et al. 2012), except for $\mathrm{Mg}$ and $\mathrm{Mn}$.

Pearson correlation between essential metals in pregnant and non-pregnant women revealed that most of the essential metals; $\mathrm{Ca}(\mathrm{r}=0.79), \mathrm{Cu}(\mathrm{r}=0.61)$, $\mathrm{Fe}(\mathrm{r}=0.85), \operatorname{Mg}(\mathrm{r}=0.68)$ and $\mathrm{Zn}(\mathrm{r}=0.91)$ were strongly correlated (except $\mathrm{Mn}$ with $\mathrm{r}=0.57$ ) indicating that they may have common source. On the other hand non-essential metals; $\mathrm{Cd}(\mathrm{r}=0.64), \mathrm{Ni}(\mathrm{r}=$
$0.43)$ and $\mathrm{Pb}(\mathrm{r}=0.44)$ were weakly correlated, signifying that they are not from same source.

Human exposure to metals in the general environment is usually greater through food and drink than through air. Even in occupational circumstance exposure to metals by ingestion may be of importance although assumption following inhalation is usually of primary concern. Levels of $\mathrm{Pb}$ in blood of the pregnant women were lower as compares to $40 \mu \mathrm{g} / 100 \mathrm{~mL}$ recommended for women of child bearing age by health and safety executives UK, $50 \mu \mathrm{g} / 100 \mathrm{~mL}$ by Finnish institute of occupational health and $30 \mu \mathrm{g} / 100 \mathrm{~mL}$ for women less than 40 years of age by Deutsche Forschuns Gemeinschaft but give no cause for concern, since it is an indication of low blood lead burden in the subjects and consequently to their fetuses, which can be susceptible to the harmful effects of $\mathrm{Pb}$ through Paraplacental transfer (Schmidt, 1992). The $\mathrm{Pb}$ levels obtained in this study were also lower than threshold of concern blood $\mathrm{Pb}$ levels of 10 ng/dL stipulated by the US Centre for disease Control (ATSDR, 1999). Low level of iron in blood is a cause for concern, because iron deficiency affects in particular women of reproductive age, resulting in adverse pregnancy outcomes, such as low birth weight, still birth, and high rates of maternal mortality (Welch and Graham, 1992). Metals and their compounds occur naturally in food and drinking water since they are intrinsic components of the earth's crust and of various biota (Flood et al. 2012, Xie et al. 2013, AMAP, 2011).

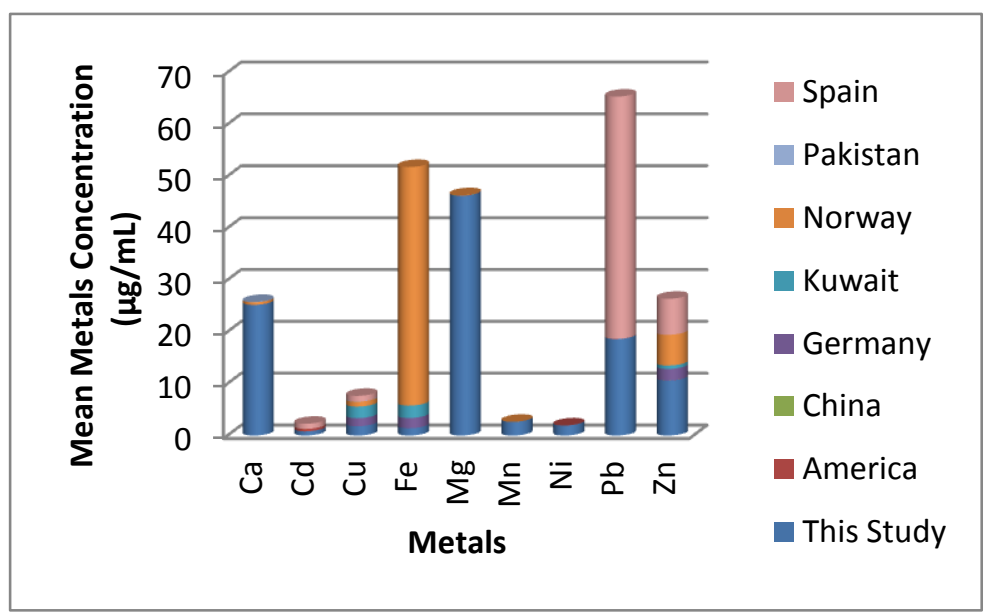

Fig 5 Comparison of metals concentration in this study with similar work reported Elsewhere

Comparison of results obtained in blood samples in this study with similar studies elsewhere (Figure 5), showed that levels of $\mathrm{Cd}$ and $\mathrm{Pb}(0.82$ and 18.60 $\mu \mathrm{g} / \mathrm{mL})$ were higher than the reported levels in Spain. Similarly mean levels of $\mathrm{Cu}$, and $\mathrm{Zn}$ (1.80, and 10.6 $\mu \mathrm{g} / \mathrm{mL}$ ) determined in this study are higher than reported concentrations in Norway and Germany while concentrations of $\mathrm{Cu}$ and $\mathrm{Fe}$ are lower than those of Kuwait. Furthermore, mean concentration of $\mathrm{Fe}$ obtained in this study are lower than those reported in Norway and Germany. Likewise reported $\mathrm{Mg}$ levels from Norway and China were lower than the values in this study $(46.23 \mu \mathrm{g} / \mathrm{mL})$. The differences may be due to difference in geographical locations, dietary habits, genetic variations, socioeconomic status, and traditions among others 
(Eyad et al., 2006, Gellein et al., 2008, Moreno et al., 1999, Mumtaz, 1999, Raja et al. 2009, Xilei et al. 1988).

Conclusions: In this study, levels of calcium, cadmium, copper, iron, magnesium, manganese, nickel, lead and zinc have been determined in the whole blood of fifty pregnant women and twenty five non - pregnant women's blood (controls) of age groups between 15 - 45 years by Flame Atomic Absorption Spectrophotometer after microwave induced acid digestion. Women with age group 25 29 years represent the largest population while seventy two percent of subjects studied had tertiary education. Highest concentration of non - essential metals in blood was detected in nurses. Statistical analysis of data using descriptive and inferential statistics revealed that age, education and profession have effect on the metals levels in the blood analysed. Generally most of the metals reported in blood in this study were of similar concentrations when compared with those reported elsewhere.

Acknowledgement: The authors would like to thank the ethics and research committee of Obafemi Awolowo University Teaching Hospitals Complex, Ile-Ife, Nigeria, for the research clearance certificate and the staffs of the hospital's labour ward unit for their assistance with the sampling.

\section{REFERENCES}

Hinwood, L., Callan, A.C., Ramalingam, M., Boyce, M. Heyworth, J. 2013. Cadmium, lead and mercury exposure in non-smoking pregnant women. Environ Research 126: 118-124.

Isabelle S., Elly D. H, Vera N. E. Nik V. L. 2013. Prenatal exposure to environmental contaminants and behavioural problems at age $7-8$ years. Environ Inter 59: $225-231$

Boekelheide K, Blumberg B, Cote I, Graziano J.H, Janesick A, 2012. Predicting later-life outcomes of early-life exposures. Environ Health Perspect 120:1353-61.

Ogunfowokan, A.O., Kaisam, J.P. and Balogun, M.O. 2009. Study of Trace Metals in Urine of Some Nigerian Medical Patients. Tox EnviroN Chem 91: 435 $-449$

Sabrina L, Jordi J, Carmen I., Nerea L., Mireia G., Marisa R. 2013. Prenatal and postnatal insecticide use and infant neuropsychological development in a multicenter birth cohort study. Env Inter 59: 175-182

Kippler, M., Tofail, F., Hamadani, J. D., Gardner, R. M., Bottai M. 2012. Early-life cadmium exposure and child development in 5-year-old girls and boys: a cohort study in rural Bangladesh. Environ Health Perspect, 120:1462-8.

Yahaya M.I., Ezeh, G.C., Musa, Y.F. Yelwa A.S. 2010. Analysis of heavy metals concentration in road side's soil in Yauri, Nigeria, African J Pure Appl Chem 4(3): 022- 030 .

Koureas, M., Tsakalof, A., Tsatsakis, A. 2012. Systematic review of biomonitoring studies to determine the association between exposure to organophosphorus and pyrethroid insecticides and human health outcomes. Toxicol Lett 210:155-68.

Llop, S., Casas, L., Santa, M. L., Esplugues A. 2013. Prenatal and postnatal residential usage of insecticides in a multicenter birth cohort in Spain. Sci Total Environ 445-446C: 273-80.

Erzen, I. and Kragelj, L.Z. 2006. Cadmium Concentration in Blood Related to Smoking Habits in a Group of Males aged Between 10 and 26 years. Trace Metals and Electrolytes 23: 60 - 5 .

Ogunfowokan, A.O., Kaisam, J.P., Balogun, M.O. Adelusola, K.A. 2008. Analysis of $\mathrm{Cd}, \mathrm{Cu}, \mathrm{Pb}, \mathrm{Zn}, \mathrm{Hg}$ and $\mathrm{Mn}$ in Kidneys and Liver from Human CadaversA Case Study in South Western Nigeria, Tox Environ Chem 90: $653-662$

Lidia M. Jaime M. Manuel.a R. Jos’e L. 2012. Correlations between Different Heavy Metals in Diverse Body Fluids: Studies of Human Semen Quality, Advances in Urology, Hindawi Publishing Corporation, doi:10.1155/2012/420893

Michael S. B., Germaine M. B., Louis, R. S., Paul J. K., Jinesh J. 2011. Associations between blood metals and fecundity among women residing in New York State. Reprod Toxicol. 31(2): 158-163.

Koutra, K., Chatzi, L., Roumeliotaki, T., Vassilaki, M. 2012. Socio-demographic determinants of infant neurodevelopment at 18 months of age: mother- child cohort (Rhea Study) in Crete, Greece. Infant Behavioural Development 35:48-59.

Callan, A.C., Hinwood, A.L., Ramalingam, M., Boyce, M.C., Odland, J.O. 2013. Maternal exposure to metals - concentrations and predictors of exposure. Environ. Res. http://dx.doi.org/10.1016/j.envres. 2013

Memon, A.R., Tasneem, G.K., Hassan, I.A. and Nasreen, S. 2007. Evaluation of Zinc Status in Whole Blood and Scalp Hair of Female Cancer Patients, Clinica Chimica Acta 10564

Bello, M., Ambe, J., Yahaya, S., Omotara, B. 2009. Traditional Birth Attendants: Practices and Problems in Konduga Local Government Area of Borno State; North Eastern Nigeria. The Internet J Tropical Med 6(1).

Godfrey, M. and Rockers C. 2009. Dissatisfaction with traditional birth attendants in rural Tanzania, Inter $J$ Gyn Obst 107: 8 - 11

Itinal, S.M. 1997. Characteristics of traditional birth attendants and their beliefs and practices in the Offot Clan, Nigeria, World Health Organization Bulletin 75 
Funda, K., Kamil, S., Serap, A. 2004. Determination of the Levels of $\mathrm{Zn}, \mathrm{Cu}, \mathrm{Ca}$, and $\mathrm{Mg}$ of Chios Ewes in the Aydim Region, Turkish J Vet Ani Sci 28: 609 - 612

National Academy of Sciences (NAS). 1974. Recommended Dietary Allowance, $8^{\text {th }}$ ed. Washington.

Minoia, C. and Sabbioni, E. 1990. Trace Metals Reference Values in Tissues from Inhabitants of the European Community: A case Study of 46 Metals in Urine, Blood and Serum of Italian Subjects. Science and Total Environment 95: 89 - 105

Burtis, C.A. and Ashwood, E.R. 1996. (ed) Tiez Textbook of Clinical Chemistry 4th edition WB Saunders Philadelphia, $490-2$.

Oboro, V.O., Tabowei, T.O., Agu, D. 2003. Pregnancy Outcome among Teenagers in Suburban Nigeria, Journal of Obstetrics and Gynaecology 23: 166 - 9.

Ojofeitimi, E.O., Elegbe, E. and Babatunde J. 1982. Diet Restriction by Pregnant Women in Nigeria, Int J Gyn Obst 20: 19 - 103.

Fei C, Olsen J. 2011. Prenatal exposure to per fluorinated chemicals and behavioural or coordination problems at age 7 years. Environ Health Perspect, 119:573-8.

Gallagher, C., Chen, J., Kovach,J. 2011. The relationship between body iron stores and blood and urine cadmium concentrations in US never-smoking, nonpregnant women aged 20-49 years. Environ. Res 111: 702-707.

Jain R.B. 2010. Effect of pregnancy on the levels of blood cadmium, lead and mercury for females aged 17-39 years old: data from the National Health and Nutrition Survey 2003-2010 J. Toxicol. Environ. Health 76(1):58-69.

Tofail, M., Gardner, F. Rahman, R., Bottai, J.D., Vahter, M., 2012. Maternal cadmium exposure during pregnancy and size at birth: a prospective cohort study. Environ. Health Perspect. 120:284-288.

Schmidt, W. 1992. The amniotic fluid compartment: The Fetal Habitat, Berlin: Springer - Verlag.
Agency for Toxic Substances and Disease Registry Toxicological [ATSDR] 1999. Profile for Cadmium (update), US Department of Health and Human Services. Atlanta.

Welch, R.M. and Graham, R.D. 1992. Breeding Crops for Enhanced Micronutrient Content, Plant and soil 245: $205-210$.

Flood, A.P., Chiang, K., Herring, S., Wolf, A.H., Fry, R.C. 2012. Towards prenatal monitoring in North Carolina: Assessing arsenic, cadmium, mercury and lead levels in pregnant women. http: //dx.doi.org/10:1377/journal.pone.0031354.

Xie, X., Ding, G., Zhou, Y., Shi, R., Ying, T., 2013. The effects of low- level prenatal lead exposure on birth out comes. Environ Pollut. 175:30-34.

Arctic Monitoring and Assessment Programme [AMAP]. 2011. Mercury in the Artic. Oslo. Available: 〈http://www.amap.no/〉 [accessed 21December 2013].

Eyad, A., Moorkath, N., Jehad, A. and Hude A. 2006. Maternal- Fetal status of Copper, Iron, Molybdenum, Selenium and Zinc in obsessed pregnant women in late gestation. Biological Trace Metals Research 113

Gellein, K.S., Jon, H., Aaseth, J., Flaten, T. P. 2008. Trace metals in cerebrospinal fluid and blood from patients with a rare progressive central and peripheral demyelinating disease, J Neuro Sci 266: 70 - 78 .

Moreno, M.A., Marin, C., Vinagre, F. and Ostapczuk, P. 1999. Trace element levels in whole blood samples from residents of the city Badajoz, Spain. Science and Total Environment 229: 209 - 215

Mumtaz, M., Siddique, V., Mukhtar, N. and Mehboob, T. 1999. Status of Trace Metals Level in Blood Samples of different Age Population of Karachi (Pakistan), Turkish Journal of Medicinal Science 29: 697 - 699.

Raja, P., Suresh, G., Marichamy, G. 2009. Heavy metals concentration in four commercially valuable marine edible fish species from Parangipettai coast, South East coast of India, Int J Ani Vet Advan 1(1): 10-14

Xilei, L., Renterghem, D.V. Cornelis, R. and Mess, L. 1988. Radiochemical Neutron Activation Analysis of 13 Trace Metals in Human Blood Serum by Inorganic Ion Exchanger, Analytical Chimica Acta 211: 231 24 